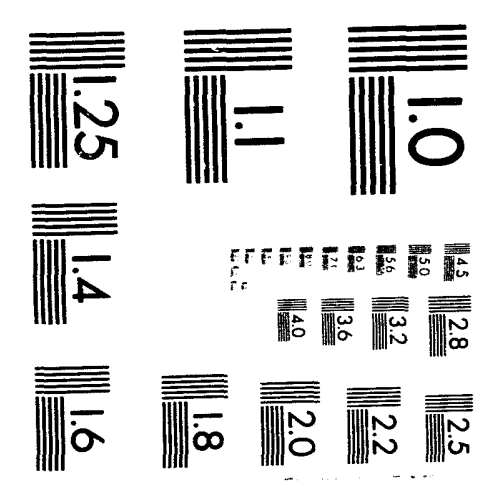



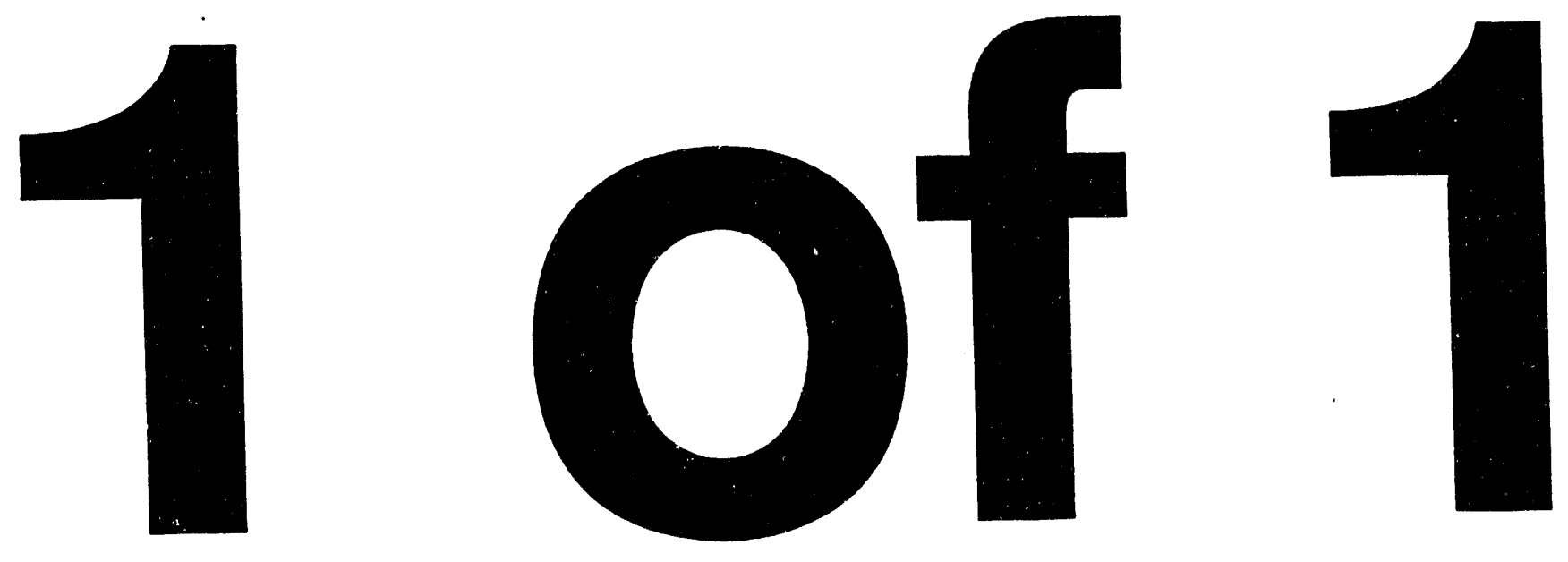


\section{PARTICULATE BEHAVIOR IN A CONTROLLED-PROFILE PULVERIZED COAL-FIRED REACTOR: A STUDY OF COUPLED TURBULENT PARTICLE DISPERSION AND THERMAL RADIATION TRANSPORT}

Quarterly Technical Progress Report For Period September 15, 199 $\frac{3}{2}$ to December 14, 1993

Mardson Queiroz and Brent W. Webb

Brigham Young University

Provo, UT 84602

\section{Prepared for the United States Department of Energy \\ PIttsburgh Energy Technology Center (PETC)}

Under Contract No. DE-FG22-91PC91308

"US/DOE Patent Clearance is not required prior to the publication of this document" 


\section{DISCLAIMER}

This report was prepared as an account of work sporcored by the United States Government. Neither the United States nor the United States Department of Energy, nor any of their employees nor any of their contractors, subcontractors, or their employees, makes any warranty, expressed or implied, or assumes any legal liability or responsibility for the accuracy, completeness, or usefulness of any information, apparatus, product or process disclosed, or represents that its use would infringe privately owned rights. 


\section{FORWARD}

This report summarizes technical progress during the nineth quarter (September 15, 1993 to December 14, 1993) of a three-year study conducted for the Department of Energy (DOE) under contract number DE-FG22-91PC91308. The principal investigators for this work are Dr. Mardson Queiroz and Dr. Brent W. Webb; Dr. Clifford Smith is the technical representative for DOE. 
TABLE OF CONTENTS

PAGE

DISCLAIMER

FORWARD

ABSTRACT

Iv

1. OBJECTIVES AND SCOPE

1.1 BACKGROUND

1.2 OBJECTIVES

1

1.3 TECHNICAL APPROACH

1

2

3. SUMMARY OF TECHNICAL PROGRESS

2.1 RADIATION AND PARTICLE DISPERSION MODELLING

3. REFERENCES

4. APPENDIX 


\section{ABSTRACT}

During the nineth quarter progress has been made in the following areas: (1) reduction of experimental data recently collected; (2) particle dispersion and readiation modelling. 


\section{OBJECTIVES AND SCOPE}

\subsection{BACKGROUND}

Improved understanding of the fundamental processes involved in pulverized-coal combustion is needed to rnake the energy extraction more efficient and the combustion byproducts environmentally safe. While the characterization of the local particulate behavior (concentration, size, and velocity) is important to the understanding of virtually all processes in a pulverized coal-fired furnace, it influences in a more direct way the turbulent particle dispersion and thermal radiation heat transfer. Yet the local particulate dynamics have gone relatively unaddressed, primarily because of lack of adequate instrumentation to carry out such a study. With recent advances in optical techniques such an effort is now possible. This proposal seeks to characterize the local particulate concentration, velocity, and size distribution in a wellcontrolled, parametrically-varied laboratory-scale reactor using a new laser diagnostic technique. This newly-developed technique is the only one currently available for the investigation of aspherical particles. The particulate data will be collected simultaneously with local gas temperature and wall radiant heat flux distributions.

\subsection{OBJECTIVES}

This report describes recent progress in a fundamental, three-year investigation of the coupled problem of turbulent particle dispersion and thermal radiation transport. The project's objective is to make measurements of particle size, velocity, number density, temperature and wall radiant heat flux in a parametrically-controlled reactor presently existent at Brigham Young University (BYU). Although the study proposed here is primarily designed to provide experimental data not currently available for the evaluation of turbulent particle dispersion and radiation models, comparisons of analytical predictions and the experimental data obtained will be performed, using appropriate submodels integral to comprehensive pulverized-coal combustion codes existent at BYU.

\subsection{TECHNICAL APPROACH}

To accomplish the above objectives, the project is divided in the following tasks:

- Design and fabrication of a modified section for the BYU controlled-profile reactor, which will allow access of several probes to be used in the proposed study.

- Design and fabrication of a two-color pyrometer and cooled probe for local particulate temperature measurement.

- Characterization of the non-reacting turbulent flow field in the reactor using the PCSV-P probe, which will serve as an input during the turbulent particle dispersion submodel validation.

- Literature review dealing with particle dispersion and radiation transport in support of the model validation effort. 
- Perform the parametrically-controlled measurements in the controlled-profile reactor.

- Experimental data analysis.

- A comprehensive comparison of experimental data and model predictions.

- Final report.

\section{SUMMARY OF TECHNICAL PROGRESS}

\subsection{RADIATION AND PARTICLE DISPERSION MODELLING}

Work is proceeding on the development of the radiative transfer model. A discrete ordinates solver for the Radiative Transfer Equation has been written for the axisymmetric configuration of the Controlled Profile Reactor. The radiative properties of the flame studied have been calculated from the comprehensive set of field measurements which included particle number density of various size classes, percent ash in the particulates, gas and particle temperatures, $\mathrm{CO}_{2}$ partial pressure, and wall temperatures. Linear interpolation was performed to obtain field values at grid locations. The measured values taken closest to the walls were assumed to prevail up to the wall. If the particles are approximated as spherical, homogeneous, and the complex index of refraction is known, the radiative properties of the polydispersions can be predicted using Mie theory (Van de Hulst, 1957; Bohren, 1983). Measured particle number densities (Bonin, 1992) were divided into eight size groups: $0.5,1.1,5,10,20,30,40$, and $45 \mu \mathrm{m}$. Both gray and spectral radiation transfer analyses were performed in this study. The char radiative properties were calculated assuming spectrally independent index of refraction of high-volatile bituminous of $1.85-0.22 i$ which is representative of values reported in the literature (McCartney and Ergun, 1958; Blokh and Burak, 1973; Huntjens and van Krevelen, 1954). In those references, the index of refraction of bituminous coal was shown to depend only weakly on wavelength. The imaginary part of the index of refraction of fly-ash, on the other hand, is strongly spectrally dependent, varying several orders of magnitude. The spectral dependence of the index of refraction of fly-ash was taken from Goodwin and Mitchner (1989). Due to the highly forward scattering properties of pulverized coal (Mengüç and Manickavasagam, 1991), the scattering phase function was modeled with the Dirac-delta approximation as outlined by Crosbie and Davidson 91985). The radiative properties of the combustion gases $\left(\mathrm{CO}_{2}\right.$ and $\left.\mathrm{H}_{2} \mathrm{O}\right)$ were calculated from the Edwards wide band model (Edwards, 1976). $\mathrm{H}_{2} \mathrm{O}$ concentrations were not measured since a water-cooled probe was used. No effort was made to experimentally measure the condensate from the combustion gases. Therefore, the $\mathrm{H}_{2} \mathrm{O}$ partial pressure was estimated from the stoichiometric ratio with $\mathrm{CO}_{2}$. The gray absorption coefficient for the gas mixture was obtained from the effective emissivity as

$$
\kappa_{\text {gas }}=-\ln \left(1-\varepsilon_{\text {gas }}\right) / L
$$


where $\varepsilon_{\text {gas }}$ is the gas emissivity and $L$ is an appropriate path length. The spectrally dependent absorption coefficient for soot was taken from the relation $\kappa_{\lambda}=7 f_{v} / \lambda$ (Hottel and Sarofim, 1967), where $f_{v}$ is the volume fraction of the soot which has been reported in the range of $7 \times 10^{-8}$ to $4 \times 10^{-6}$ (Bard and Pagni, 1981). The baseline soot volume fraction was estimated as $3 \times 10^{-6}$. The factor 7 which appears in the expression for $\kappa_{\lambda}$ of soot is not unique but depends on the complex index of refraction of the soot.

Figure 1 shows the predicted incident radiative wall flux using level symmetric quadratures of $S_{4}$. $S_{6}$, and $S_{8}$ compared to the measured incident wall flux. The $S_{4}$ predicted flux is about $7 \%$ above the measurement at an axial distance of 30 to $40 \mathrm{~cm}$. The $S_{6}$ and $S_{8}$ show better agreement in this region. Using low $S$ quadrature orders in problems with regions of high temperature gradients can result in less accuracy due to the ray effect. The predictions agree very well with the measured wall incident fluxes. Work is continuing on the predictive capability, refining the radiative property submodels.

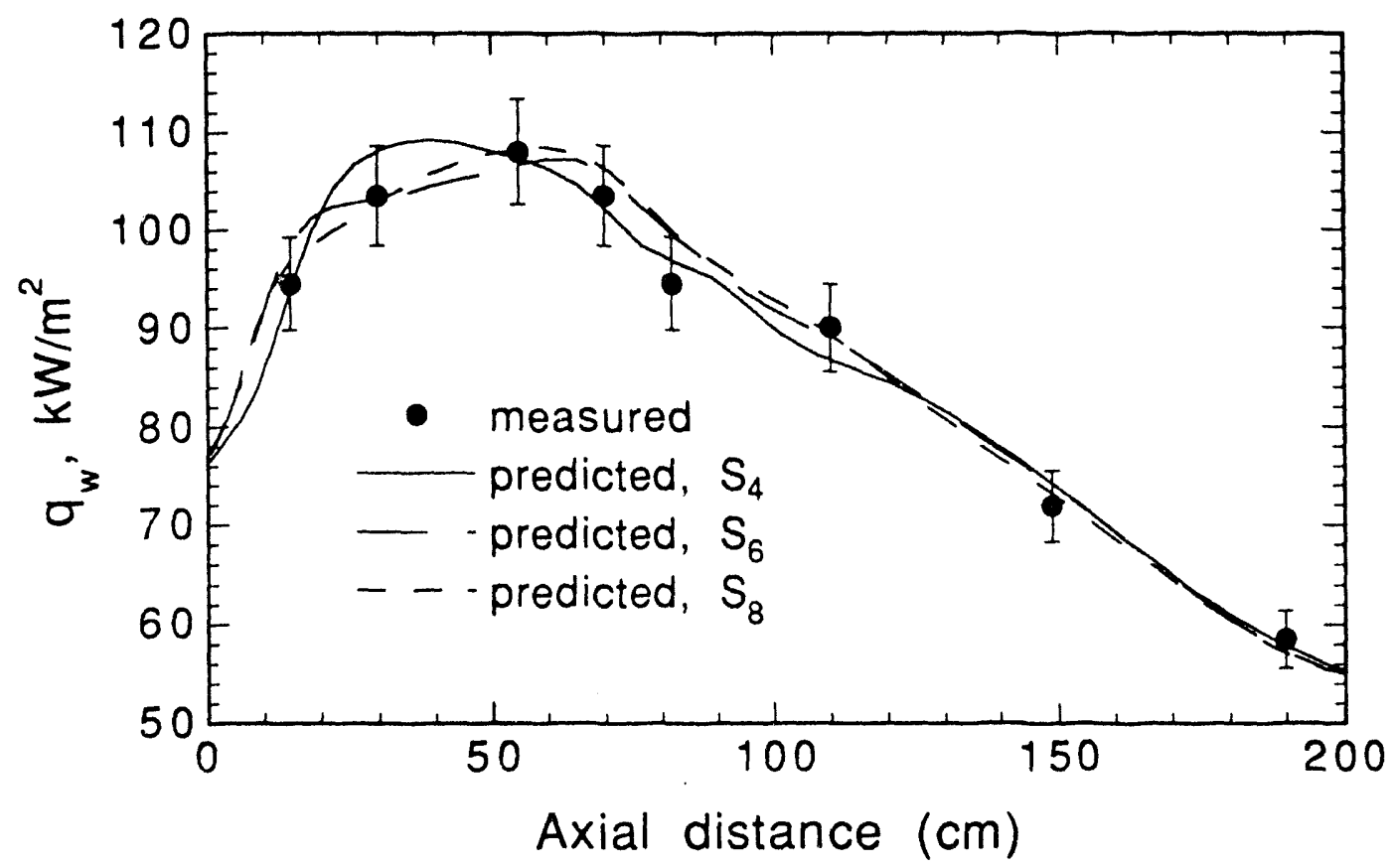

Figure 1. Measured and predicted incident wall radiant heat flux profile using $S_{4}, S_{6}$, and $S_{8}$ discrete ordinates. 
Work on the validation of an existing particle dispersion model continues with comparisions with existing experimental data. The experimental data from Bonin (1992) can be classified into two different flow conditions: (1) isothermal or nonreacting flow, and (2) reacting flow. The isothermal flow and reactive test matrices are illustrated in Tables 1 and 2, respectively.

Test $1 \mathrm{C}$ to $4 \mathrm{C}$ were performed by varying the swirl number and the secondary air temperature. Test $1 \mathrm{C}$ and $3 \mathrm{C}$ were the nonswirling flows with difference in the secondary air temperature. A swirl number of 1.4 was used for test conditions $2 \mathrm{C}$ and $4 \mathrm{C}$; again, the only difference between these two tests was the secondary air temperature. All the reacting test conditions except Test $5 \mathrm{H}$ used a swirl number of 1.4. Test $5 \mathrm{H}$ is identical to Test $4 \mathrm{H}$ except that it has a lower swirl number. Test $3 \mathrm{H}$ differs from Test $4 \mathrm{H}$ in terms of the initial coal-size distribution used. Test $2 \mathrm{H}$ used higher secondary air as compared to Test $1 \mathrm{H}$.

A Utah Blind Canyon coal was used for buth isothermal and reacting tests. Some other important input parameters required for the code simulation are the proximate and ultimate analyses as well as the initial coal-size distribution used during the experiments. Table 3 gives the proximate and ultimate analyses provided by the Utah Power and Light Corporation for the various shipments received from the power plant. It can be seen from Table 3 that there is very little variation between each group of coal received from the power plant. The initial coal-size distribution used for isothermal cases had a mass mean diameter of $52 \mu \mathrm{m}$ (Table 1). For the reacting test conditions two different initial coal-size distributions were used, i.e., $22 \mu \mathrm{m}$ and $55 \mu \mathrm{m}$ (Table 2).

For the purpose of simulating the reacting test conditions on PCGC-2, Test $4 \mathrm{H}$ is chosen to be the base case. All the initial trial runs were conducted for this test condition. Once all the input parameters are fine-tuned to achieve the best possible predictions for this case, these input file can be later used with appropriate changes to simulate the other reacting test conditions. Similarly for the isothermal test conditions, Test $1 \mathrm{C}$ will be used as the base case.

The equations which evaluate the particle trajectories depend on the solution of the gas-phase equations. Therefore, it is expected that parameters influencing the gas-phase predictions will affect the dispersion predictions. Input parameters, namely the inlet turbulence intensities and the inlet velocity profiles, influence the gas-phase predictions; hence it is important to study its effect on dispersion predictions. However, sensitivity studies conducted by Smith (1992) show that the uncertainties associated with inlet turbulent intensities had showed little or no impact on PCGC-2's predictions. Studies conducted on comprehensive, pulverized-coal combustion codes similar to PCGC-2 also indicate that the predictions are insensitive to the employed turbulence intensities. The turbulence intensity of $10 \%$, which is a good estimate of the turbulence level for the operating condition present in this study, will be used to characterize the inlet turbulent intensity of both the primary and secondary streams. Furthermore, Lockwood and Mahmud (1988) studied the sensitivity of predictions to inlet flow conditions by replacing the measured velocity profiles with uniform profiles. Their results show that the predicted flow field and the resulting flame were somewhat sensitive to the inlet velocity profile. In the present case, due to the 
nonavailability of measured velocity profiles, it was decided to use a uniform inlet velocity profile for simulation purposes.

\section{REFERENCES}

Bard, S. and Pagni, P. J., 1981, "Carbon Particulates in Small Pool Fire Flames," ASME J. Heat Transfer, Vol. 103, 357-363.

Blokh, A. G. and Burak, L. D., 1973, "Radiation Characteristics of Solid Fuels," Teploenergerika, Vol. 2', 48-52.

Boiiren, C. F. and Huffman, D. R., 1983, Absorption and Scattering of Light by Small Particles, Wiley.

Bonin, M.P., Optical Measurement Of Particle Size, Velocity And Number Density In Pulverized Coal Flames, Ph.D. Dissertation, Brigham Young University, Provo, Utah, 1992.

Costa, M., Costen, P., Lockwood, F. C., and Mahmud T., Detailed measurements in and modelling of an industry-type pulverised-coal flame, 23rd symposium (Intl.) on Combustion / The combustion institute, pp 973-980, 1990.

Crosbie, A. L. and Davidson, G. W., 1985, "Dirac-Delta Function Approximations to the Scattering Phase Function," J. Quant. Spect. Rad. Transfer, Vol. 33, 391-409.

Edwards, D.K., 1976, "Molecular Gas Band Radiation," Advances in Heat Transfer, Vol. 12, 115-193, Academic Press, New York.

Goodwin, G. D. and Mitchner M., 1989, "Infrared Optical Constants of Coal Slags," AlAA J. Thermophysics Heat Transfer, Vol. 3, 53-60.

Hottel, H.C. and Sarofim, A.F., 1967, Radiative Transfer, McGraw-Hill, New York.

Huntjens, F. J. and van Krevelen, D. W., 1954, "Chemical Structures and Properties of Coal: II-Reflectance," Fuel, Vol. 33., 88-103. 
Lockwood, F.C. and Mahmud, T., The prediction of swirl burner pulverised coal flames, 22nd Symposium (Intl.) on combustion / The combustion institute, pp 165-173, 1988.

McCartney, J. T., and Ergun, S., 1958, "Optical properties of Graphite and Coal," Fuel, Vol. 37, 272-282.

Mengüç, M. P. and Manickavasagam, D. d'SA, 1991, "Determining the Radiative Properties of PulverizedCoal Particles from Experiments," 3rd ASME/JSME Thermal Eng. Conf., Reno, Nevada, March.

Smith, J.D., A detailed evaluation of comprehensive simulation software describing pulverized-coal combustion and gasification using advanced sensitivity analyses techniques, Ph.D. Dissertation, Brigham Young University, Provo, Utah, 1990.

van de Hulst, H. C., 1957, Light Scattering by Small Particles, Wiley and Sons, New York (1981 Dover Edition), 1957. 
Table 1. Isothermal flow test matrix. ${ }^{1}$

\begin{tabular}{|c|c|c|c|c|c|c|}
\hline TEST & SWIRL & $\begin{array}{c}\text { PRIMARY } \\
\text { AIR FLOW }\end{array}$ & $\begin{array}{c}\text { SECOND. } \\
\text { AIR FLOW }\end{array}$ & $\begin{array}{c}\text { COAL FEED } \\
\text { RATE }\end{array}$ & WALL & $\begin{array}{c}\text { SECOND. } \\
\text { TEMP. }\end{array}$ \\
\hline $1 \mathrm{C}$ & 0.0 & 15 & 126 & 11.4 & 300 & 300 \\
\hline $2 \mathrm{C}$ & 1.4 & 15 & 126 & 11.4 & 300 & 300 \\
\hline $3 \mathrm{C}$ & 0.0 & 15 & 126 & 11.4 & 300 & 380 \\
\hline $4 \mathrm{C}$ & 1.4 & 15 & 126 & 11.4 & 300 & 380 \\
\hline
\end{tabular}

Table 2. Reacting flow test matrix. ${ }^{1}$

\begin{tabular}{|c|c|c|c|c|c|}
\hline $\begin{array}{c}\text { TEST } \\
\#\end{array}$ & $\begin{array}{c}\text { SWIRL } \\
\text { NUMBER }\end{array}$ & $\begin{array}{c}\text { EQUIVALENCE } \\
\text { RATIO* }\end{array}$ & $\begin{array}{c}\text { COAL FLOW } \\
\text { RATE }\end{array}$ & $\begin{array}{c}\text { MASS-MEAN } \\
\text { PARTICLE SIZE }\end{array}$ & $\begin{array}{c}\text { SECONDARY AIR } \\
\text { FLOW RATE }\end{array}$ \\
\hline $1 \mathrm{H}$ & 1.4 & 1.0 & $11.4 \mathrm{~kg} / \mathrm{hr}$ & $22 \mu \mathrm{m}$ & $108 \mathrm{~kg} / \mathrm{hr}$ \\
\hline $2 \mathrm{H}$ & 1.4 & 1.3 & 11.4 & 22 & 145 \\
\hline $3 \mathrm{H}$ & 1.4 & 1.15 & 11.4 & 22 & 126 \\
\hline $4 \mathrm{H}$ & 1.4 & 1.15 & 11.4 & 55 & 126 \\
\hline $5 \mathrm{H}$ & 1.0 & 1.15 & 11.4 & 55 & 126 \\
\hline
\end{tabular}

\footnotetext{
- Calculated as the ratio of present [oxidizer/fufl] to [oxidizerffuel] at stoichiometric conditions.
} 
Table 3. Properties of Utah Blind Canyon Coal over several shipments. ${ }^{1}$

\begin{tabular}{|c|c|c|c|c|c|c|c|}
\hline \multicolumn{4}{|c|}{ PROXIMATE/ULTIMATE ANALYSIS } & \multicolumn{4}{|c|}{ ASH COMPOSITION } \\
\hline & \multicolumn{3}{|c|}{ As Received } & & \multicolumn{3}{|c|}{ As Received } \\
\hline & $\begin{array}{c}\text { Group } \\
1 \\
5 / 91 \\
\end{array}$ & $\begin{array}{c}\text { Group } \\
2 \\
8 / 91 \\
\end{array}$ & $\begin{array}{c}\text { Group } \\
3 \\
9 / 91 \\
\end{array}$ & & $\begin{array}{c}\text { Group } \\
1 \\
5 / 91 \\
\end{array}$ & $\begin{array}{c}\text { Group } \\
2 \\
8 / 91 \\
\end{array}$ & $\begin{array}{c}\text { Group } \\
3 \\
9 / 91 \\
\end{array}$ \\
\hline Moisture & $8.43 \%$ & $8.54 \%$ & $9.23 \%$ & Sulfur Trioxide & $4.02 \%$ & $4.48 \%$ & $3.94 \%$ \\
\hline Ash & 12.74 & 13.25 & 12.74 & Aluminum Oxide & 15.29 & 15.08 & 15.34 \\
\hline Volatile & 39.71 & 39.35 & 39.00 & Ferric Oxide & 2.90 & 2.76 & 2.96 \\
\hline Fixed Carbon & 39.13 & 38.86 & 39.03 & Titanium Oxide & 0.87 & 0.80 & 0.80 \\
\hline Sulfur & 0.48 & 0.46 & 0.49 & Calcium Oxide & 7.44 & 7.34 & 7.66 \\
\hline $\begin{array}{l}\text { Heating Value } \\
\mathrm{kJ} / \mathrm{kg} \mathrm{L}\end{array}$ & 5,530 & 5,476 & 5,459 & $\begin{array}{l}\text { Magnesium } \\
\text { Oxide }\end{array}$ & 2.59 & 2.61 & 2.52 \\
\hline Carbon & 69.61 & 69.13 & 69.37 & Sodium Oxide & 2.50 & 2.34 & 2.52 \\
\hline Hydrogen & 5.26 & 5.18 & 5.18 & Potassium Oxide & 1.34 & 1.43 & 1.39 \\
\hline Nitrogen & 1.33 & 1.34 & 1.34 & Silicon Dioxide & 61.12 & 62.04 & 60.91 \\
\hline \multirow[t]{5}{*}{ Oxygen } & 9.40 & 9.37 & 9.61 & & & & \\
\hline & & & & $\begin{array}{r}\text { ASH FUSI } \\
\text { ('K }\end{array}$ & $\begin{array}{r}\text { DN TEM } \\
\text { Reduc } \\
\end{array}$ & $\begin{array}{l}\text { ERATUF } \\
\text { Ing) }\end{array}$ & \\
\hline & & & & & $\begin{array}{c}\text { Group } \\
1 \\
5 / 91 \\
\end{array}$ & $\begin{array}{c}\text { Group } \\
2 \\
8 / 91 \\
\end{array}$ & $\begin{array}{c}\text { Group } \\
3 \\
9 / 91 \\
\end{array}$ \\
\hline & & & & $\begin{array}{c}\text { Initial } \\
\text { Deformation }\end{array}$ & 1481 & 1485 & 1478 \\
\hline & & & & $\begin{array}{c}\text { Fluid } \\
\text { Temperature } \\
\end{array}$ & 1603 & 1597 & 1592 \\
\hline
\end{tabular}


4. APPENDIX

REPORT DISTRIBUTION LIST

Ms. Marilyn Keane

PM-01, MS 922-206

U.S. Department of Energy

Pittsburgh Energy Technology Center

P.O. Box 10940

Pittsburgh, PA 15236

Ms. Rhonda L. Dupree

AD-22, MS 921-118

U.S. Department of Energy

Pittsburgh Energy Technology Center

P.O. Box 10940

Pittsburgh, PA 15236

Office of Technology Transfer

Attn: Kay Downey

Mail Stop 58-M217

U.S. Department of Energy

Pittsburgh Energy Technology Center

P.O. Box 10940

Pittsburgh, PA 15236

U.S. Department of Energy

Attn: Document Control Center

Mail Stop 921-118

P.O. Box 10940

Pittsburgh, PA 15236-0940

Dr. Clifford Smith

U.S. Department of Energy

Pittsburgh Energy Technology Center

P.O. Box 10910

Pittsburgh, PA 15236 

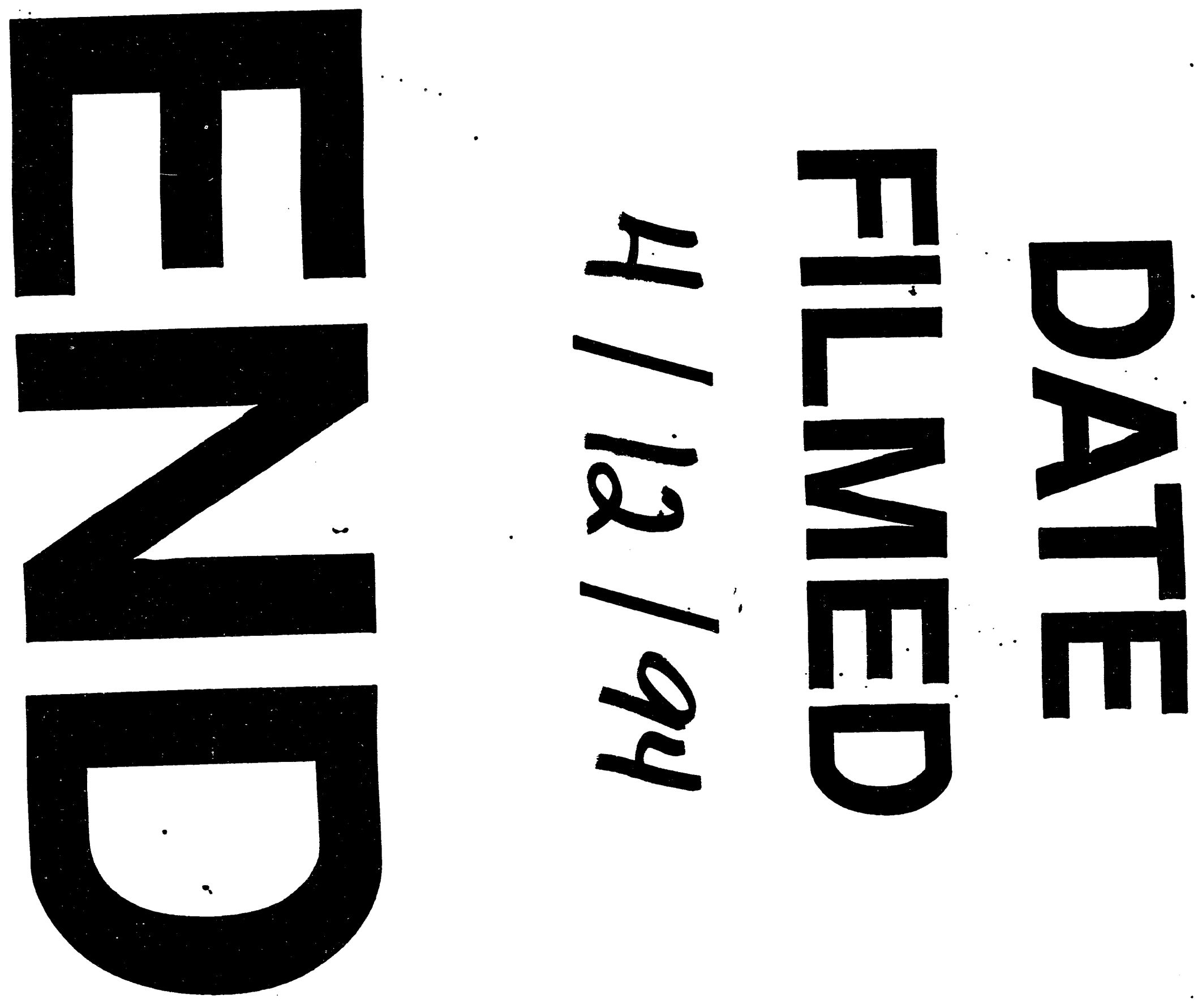
